\title{
Torn Between the Real and the Illusion: Tennessee Williams' Protagonists
}

\author{
Yousef. A.N. Aldalabeeh \\ Address: Language Center, Al-al-Bayt University, Mafraq 25113, Jordan \\ E-mail: aldalabeehyousef@yahoo.com
}

Received: 11-09-2015

Published: 01-03-2016
Accepted: 19-12-2015

doi:10.7575/aiac.ijalel.v.5n.2p.144
Advance Access Published: January 2016

URL: http://dx.doi.org/10.7575/aiac.ijalel.v.5n.2p.144

\begin{abstract}
Tennessee Williams is regarded as one of the most famous and important American playwrights in the twentieth century. His writing career spanned more than forty-five years, and his achievements have been recognized and appreciated by many critics and readers in the world. Williams' literary work was also under many critical controversies. During his life, he was awarded two times Pulitzer Prizes for his work 'A Streetcar Named Desire' in 1947 and 'Cat on a Hot Tin Roof' in 1955. He was also awarded New York Drama Critics' Circle Award for "The Glass Menagerie". His southern roots play an important role to shape the theme of his work where thematically attached to twentieth-century southern fiction writers more than any other dramatist of his period. Williams concerned much with absconders and isolated people who were treated badly and trapped in their inappropriate circumstances, and this was the outcome of the impact of the social protest in the 1930s. His plays are concerned with large individual issues rather than the social issues that differentiate him from his contemporaries by the lyrical language he used too. The paper takes up the dialogue between the real and the illusion, especially in the way his protagonist relates to their social milieu.
\end{abstract}

Keywords: Degenerate, sordid, fugitive, alienated, dialogic, real, illusion

\section{Introduction}

"If such playwrights as Eugene O'Neil, Steinberg, Susan Glaspell, Thorton Wilder, and Clifford dominate American theatre in the first half of the twentieth century and Arthur Miller, Edward Allen, Lorraine Hans Berry, Sam Shepard and David Mamet among many others, the second half, Tennessee Williams animated the middle years of the century. In a very real sense, then, Tennessee Williams inhabited the central place within the American theater. While O'Neill was the tragic dramatist and Miller remained ethical, Tennessee Williams emerged as the poet of the heart."( Roudane, 1)

Williams' plays shocked the audience since they present something that has never been presented before. Most of his plays are about murder, rape, drug addiction homosexuality, alcoholism, and even cannibalism. An extreme reaction was expressed by George Jean Nathan (as cited in Bibsby, 1984), who writes that Williams realistically dramatizes 'sexual abnormality, seduction lunacy' and makes a theatrical shocker. Presenting something that is considered as a taboo, the plays have influenced the audiences' taste, and have become a battleground for American critics.

"In Williams' cosmology imagination too is the source of both great strength and weakness".(Roudane, 1). His strength of imagination created characters like Amanda Wingfield in The Glass Menagerie, Blanche DuBois in A Street Car Named Desire, Hannah Jelkes in The Night of the Iguana and endowed them with abilities to put a heroic resistance against a contingent and bewildering universe, whereas, the weak characters are Val Xavier in Orpheus Descending, Sebastian Venable in Suddenly Last Summer, and Chance Wayne in Sweet Bird of Youth. Williams' imagination finds itself consumed (by alcoholism, blowtorch, homosexuality, cannibalism, and castration) by those whose sensibilities Kill the heroic deeds, the idealistic and the creative in this contradictory World.

Williams' characters in some of his plays are realistic. Even the events and the way in which the plot develops are realistic too. The main and significant Characters he used in his works are people he met in different locations he Experienced. For example, in A Street Car Named Desire, he portraits real Character, who worked with him at the shoe company. Like Kowalski, who described as "everything the young poet was not at ease within crowds and with strangers, his strength and confidence of his ability to charm the ladies," (Spoto 1985, 44) which could easily be used as a description of the fictional Kowalski presented in the play. The father character, in Cat on a Hot Tin Roof, known only as Big Daddy, was based on Williams' own father. At points, throughout his Memoirs, Williams refers to his father as Big Daddy, for example, while discussing the summer job he had sold women's magazines after his first year of college, Williams says: "just how this came about I don't recall but certainly I did it only to please, or should I say pacify, Big Daddy." (Spoto 1985, 28) Williams uses this term for his father to illustrate his father's large and controlling personality. 
The most autobiographical play written by Williams was The Glass Menagerie. Laura, in The Glass Menagerie, is based on Tennessee Williams' elder sister, a young woman beset by mental problems that eventually led to her being institutionalized. So Williams greatly sympathized with his sister sock that it formed his main theme. The confining nature of human existence, the loss of equilibrium and development of estrangement from his sister, was viewed by Williams as an overwhelming and irreparable loss. It left him tortured forever and 'To love is to lose' became his personal credo as he wrote in his Foreword to Sweet Bird of Youth (1969) "all my life I have been haunted by the obsession that to desire a thing or to love a thing intensely is to place yourself in a vulnerable position, to be a possible if not a probable loser of what you most want."(i)

Tennessee Williams was widely prepared to write about society's castaway and about people who were neglected in the society. During his past years, he experienced violence and abused emotionally and psychologically because of the artificial relationship with his family. Williams' father, traveling salesperson in a big shoe manufacturer, was the aloof and abusive father. He forced his son Williams to leave the school and work with him for a shoe company. His mother was an aggressive and idiosyncratic lady, maniac by her illusions of genteel southern living. He didn't have a good relationship with his younger brother, Dakin, whom his father very often loved him more than his older children.

Tennessee Williams encountered physical violence in society as a whole which was based on the philosophy of aggressive individualism. He finds writing as the way to escape from hard real world to an imagination world that gives him some comfort. He lived in a society of drop-outs, drug addicts, homosexuals, drunkards, exploited and lonely people. Williams' literary work was also deeply affected by the social and economic condition.A lot of the American people were upset and hapless because of the financial situation. The lowest economic standard they had ever been was the Great Depression. The U.S. Depression was the main cause for the American writers to write about it.

"In the Great Depression, the American dream had become a nightmare. What was once the land of opportunity was now the land of desperation. What was once the land of hope and optimism had become the land of despair. The American people were questioning all the maxims on which they had based their lives, democracy, capitalism, individualism" (Wright, 1913 25)

A large percentage of the American people were looking for new hope and a better life. They went to California to find work in agriculture or the cities of the west land, they were no more owners of the land. Tennessee Williams depicts such kind of trouble and transformation in his writing.His characters went out of the villages searching for better life in the 1920 s by marketing their plantations but, unfortunately, they were shocked by economic decline in 1929 which affected their lives and personalities. It also was instrumental in shaping his characters as outcasts, alienated and made them fugitives. They were in a hunt of an ideal world to fulfill their dreams that was next to impossible and people longed for contact and commiseration in times of turmoil. The weaker ones got involved in cheating and debauchery of all kinds to fight their hostile circumstances.

In 1920, the Nineteenth Amendment granted American women the right to vote(Phan ). As women's rights increased, so too did social freedoms. This era of 1920's provided the necessary skeleton and flesh to Tennessee Williams' dominating women characters like Amanda of The Glass Menagerie, Mrs. Venable of Suddenly Last Summer, Blanche DuBois of A Street Car Named Desire and Margaret of Cat on a Hot Tin Roof who were all products of a changing new world of modernization and sexual freedom brought by industrialization and greater women rights.

Thus, we see that 'reality,' social reality weaved itself into the woof and the warp of William's works. The reality is supposedly an objective existence independent of the perceiver, over which he does not have any control. It is supposed to exist on its own, without any relative validity arising out of the experience. The reality is not supposed to arise from experience, on the contrary, the experience is supposed to arise through observation of the objective reality. Objective reality is not supposed to be a creation of the perceiver. It has to be understood and appreciated about itself. Idealism, on the other hand, has to be understood about the individual's personal perception of the objective reality. If the perception is correspondent to the reality, it is realistic, scientific and objective. But if it is not and instead, substitutes an impression from within, whatever the reason may be, then the supposed perception is illusion. If the perception is objective, it is realistic and verifiable. If it is illusionary then, it is so because it is strictly relevant to the individual perception, thus subjective. Idealism is not verifiable, scientifically, only the perceiver may perhaps verify it after he has moved out of it. And even then, who knows that the supposed veracity of things is in fact reality and not an extended illusion.

Reality being objective remains unaffected and unchanged, whereas idealism, being the subjective perception of the perceiver, is projected out of his own notions, beliefs, desires, ambitions and imagination of life. The perceiver builds a picture of his own ideals with all sorts of imaginative coloring. Moreover, he has lived so long with his illusions that he begins to identify himself with the dreams he has unconsciously created and has been dependent upon. Since, illusions provide him the support with which he can keep himself alive in this world, therefore, he does not want to shake off the only means of the sustenance of his life. The illusion becomes a strategy of defense.

Against this background of the facts of the objective reality and the illusive experience of the mind, we see that in almost all of Tennessee Williams' plays, especially A Street Car Named Desire, The Glass Menagerie, Sweet Bird of Youth an individual carries with him or her being an image of an ideal world, but is forced to live in a world of a very different character. Williams apparently believed that the true romantic could find living palatable only through his faith in dreams and illusions. Williams seems to regard the illusions of his characters as defenses against the shipwreck of their lives. 
The American mind, in the early twenties, had become conscious of the gap between the actual and the ideal. It was the socio-cultural position that had compelled the playwrights to consider this aspect more seriously. There was a failure, something unnatural and unbelievable which affected the temper of growth utterly and completely. The tradition of progress and the myth of self-sufficiency were jolted during this period. Suddenly, the Americans were facing the rude shock to discover that progress has its limits. For the people of America it was difficult to digest it in its actual dimension, they had to take shelter in something away from the overwhelming reality. They developed and explored a particular kind of illusion, that is, the illusion of success, which is widely described regarding the acquisition of money and power. Disappointment in social life goaded them on into an imagined world of domestic happiness. Ultimately, the forming of illusions seemed to have become a necessary activity of the huge productive machinery of world's most powerful nation.

American playwrights attempted to dramatize these illusions as they saw them in society. The incessant and recurrent appearance of illusion became a fascinating feature to the contemporary American culture and society. Williams dwells on the same theme, but he does not directly criticize the obsession with money and power, rather his portrayal of these illusionary people living on the brink of society is a powerful doctrine of a society that is mainly devoted to material prosperity. A person who confines himself to his own world of dreams and illusions fails to observe the existing norms of the society; thus, different names are given to him, names such as misfit, Outsider, etc. In Williams' words, they are termed as 'fugitives'. Gerald Weales (1962) rightly says: "All of Williams' protagonists and many of his subsidiary characters are outsiders, unable to conform to the dull or cruel world in which they find themselves." (20) These underdogs, perplexed in the grip of unexpected circumstances and all powerful forces, have a particular quality of character that may be described as differentness. Weales (1977) further says: "Williams told again and again the story of an outsider, one of the fugitive kids, who by virtue of his (or her) differentness, his artistic inclinations, his sexual proclivities, his physical defects, becomes a victim of an uncongenial society." (61)

Though, most of Williams' protagonists have these qualities some of them are more prone to them than the others. For instance, Blanche becomes a sexual profligate after the death of her parents and husband. But this is not the whole truth. It was her opinion that she desperately needed sex as a stimulant after the death of her husband. Laura, in The Glass Menagerie, is crippled both by her limp and by her extra shyness. Then there is Tom, who is trying to be a poet, Chance is an ex-chorus boy, and Alexandra is a fading actress in Sweet Bird of Youth. The one quality common to all these characters is that they are illusion, and they are torn between the ideal and the actual. Tom is also trying to find an ideal world by escaping reality, the way Williams did. Williams has given some reasons, which make for an individual's yearning for a secure world, other than this earth unavoidably necessary. As he himself states: "The components are human greed, social injustice... various forms of violence and human exploitation. A favorite Williams' device is to generalize these corruptions into a single metaphor: human being treats other human beings not as arsons but as objects." (qtd. in Costello, 1977, 113)

In Sweet Bird of Youth, Boss Finley tries to sell his own daughter to a fifty-year-old moneybag. And in the same play Princess Alexandra hires Chance just for lovemaking. In Suddenly Last Summer, Catherine explains that Sebastian had 'used' first his mother and soon after he had 'used' Catherine herself as mere objects to fascinate and bombast his male companions. Val, in Orpheus Descending, (1958) extends his feeling about Jabe's burying alive woman as general behavior of the human race, "I'm telling you, Lady, there's people bought and sold in this world like carcasses of hogs in butcher shops!"(41) Williams further says that there is no alternative since the choice before man is that he can either be of this earth or a fugitive from it. He suggests that there are two types of people, the first type consists of the people who surrender to the inevitable forces; the second type consists of those who keep on struggling against these forces. Most of Williams' characters are individuals who do not accept their fate as it comes to them. Williams is mainly for the second alternative. Costello (1977) suggests: "To surrender to the evil earth is, to Williams,' man's major sin, to continue the fugitive flight is what Williams asks. The classic Williams' plea, continue the quest." (110)

Williams does not take particular pains in drawing the former kind of characters because, "that (kind) is a common lot of man, so he need not insist on it. Whoever is not a fugitive has made his place with the corrupting earth." (Costello, 113) But the paths, which these illusionary take up to avoid the corruption of the earth or to carry on their struggle, are sexuality, nostalgia for a happy life, and freedom from moral responsibilities. "They attempt to retain or regain a childlike innocence of the past, they desperately seek freedom or wildness, or they seek escape through art or sex." (Costello, 113)

Williams' characters constantly remember a sweet state, which no longer exists. Gerald Weales asserts: "all of them must look back fondly on better days, either real or fictional." (24) They, nostalgically/ try to recover a lost past. Few of the major characters in all of Williams' works are trapped within a mode of thinking which is oriented to the past. "The present exists for these men and women only to the degree that it can be verified by constant references to the past"(Davis 201). But this past with its brilliant men and women and its sophisticated way of life, disappeared, only to be replaced by a new order of life. This new life is derived from the dominant commercial and industrial interests to transform all of America into a modern technological nation. Williams' characters are unable to confront and accept their present lives, are in desperate flight from this defeated present and thus from their fears of what they have become. Trapped in time past and time future, each one falls victim to illusions, fantasies or, worse to a particular kind, of insanity. Amanda is a "little woman of great but confused vitality," (228) says Williams (1962) in his introductory notes of characters in The Glass Menagerie. Blanche Dubois, off and on, keeps remembering her old beau, Shep Huntleigh, and her aristocratic past in the tenement of Stanley. Aunt Nonnie in Sweet Bird of Youth makes it clear to Chance that 
he is craving for a time that cannot return, "what you want to go back to is your clean, unashamed youth. And you can't." (76)

Secondly, these characters long for freedom from the hard realities of life. Chance Wayne prefers to die than be tied by an "invisible loving steel chain." (103) Sandra in Battle of Angels makes the same point by saying that we are equally damned and for the same good reason because we want freedom. The attempt to escape the reality of the earth through refuge in sex is the most obvious of the possible paths, which appear to lie open before Williams' illusionary. Blanche uses sex as an equivalent substitute for a deeper human urgency, "after the death of Allan, Intimacies with Grangers was all I seemed able to fill my empty heart with." (Street Car, 205) Princess tells Chance: "I have only one way to forget these things I don't want to remember, and that's through the act of love-making." (Sweet Bird, 41)

But at the same time, Williams also suggests that with the help of this lovemaking his characters are only temporarily relieved and sometimes in the due course they suffer pain as well. Carol in a scene with Val makes it clear that sex is physically painful to her yet she desperately hunts for it: "What on earth can you do on this earth but catch at whatever comes both your hands until your fingers are broken." (Orpheus Descending, 27) Wales rightly says in this context: "... that human beings can make contact with one another only tentatively, momentarily, and that even if the touch be agonizing it is better than no communication at all." (26)

Williams, to bring home the conflict between the ideal and the actual to his readers, employs certain specific effective techniques. His best works are represented by an alliance between harsh realism and a poetic expressionism. In the play The Glass Menagerie, it is visible in the world of Jim O'Connor and Laura Wingfield. The play A Street Car Named Desire continually vacillates between the crash and clamor of Kowalski, the pungent sight, sound and smell of Stanley, the moth-like quality of Blanche, the strains of the far-away Varsouviana and the thematic cry of a street-vendor.

Although illusions are destructive, their destructive power is evident in the case of Blanche, who in the end is rendered a lunatic. Without them, it is almost unbearable for an individual to make sustenance possible in the materialistic and mechanized world, as he does not have anything to cling to. Moreover, Williams had always cared for the people who struggle for survival, no matter if this struggle was carried out with the help of dreams. Illusions give significant power and potential to this struggle. Williams, no doubt, makes it clear through this play that man cannot face reality in its actual shape but also suggests that man cannot escape reality. And to make this living palatable, even possible, he has to live with illusions, which give a false but much-needed dignity to him and help him to bear the burden of life.

Tennessee Williams' strength lies in his ability to the project spiritual isolation of men and women as a common phenomenon in an industrialized society. He does not directly criticize the obsession with money and power. But he sympathizes with the misfits and non-conformists, living on the fringe of society who are far away from material prosperity. As the characters are assaulted with the anguish of fruitless living, at odds with the world of conformists and as well as men of efficiency, they opt for a self-imposed exile that is a kind of non-recognition of the society. They are tormented by a search for some significance in living and a sense of rebellion against the futility around them. Williams cries that under the garb of our own skins we are sentenced to a lifelong solitary confinement. This feeling of isolation impels them to discover some good place of existence and also to establish some human attachment. The only task, which Williams has executed, is that he has given articulation to the repressed souls craving for expression of their musings.

The capacity to dramatize the tension between the accepted social values and the non-conformist denial of them by social outsiders is seen in its purest form in The Glass Menagerie. The play hangs on episodic and disjointed presentation of the falling apart of a representative lower middle-class family of the depression days, and it is seen that the depression was the era when America got a rude jolt after discovering that progress too has its limits. The tradition of progress and the myth of self-sufficiency were shaken during The Great Depression', and since the sixties, pessimism and disillusionment have been recognized, for the first time perhaps, as an integral part of the American Dream. But the tradition of ambition and optimize and the myth of a never-ending progress still inspire the expectations of millions.

In A Street Car Named Desire, there is an aura of security, which contrasts and contradicts the insecurity of the protagonist since Stanley's brutal secure world is opposed to Blanche's world of romance. But The Glass Menagerie does not offer even a single character in possession of his or her territory. All of them have a sort of thoughtless obstinacy, which hinders them to comprehend the social realities they are fighting against. However, they instinctively respond to the circumstances in their own respective manners. At heart, each of them is lonely and alienated, but the sense of family loyalty, so characteristic of the past generation, persists in their thoughts and actions.

Amanda, Tom, and Blanche try to live in the ideal world through wish projection and fantasizing. Unable to live in the present, they retreat into a place appropriate to their own fantasy.

The confrontation of the ideal with the actual can also be seen in the last scene, where Laura is forced to meet Jim O'Connor, who symbolizes the outside world. But, since doubts plague Jim himself, therefore, even he also lives in his own world of dreams. He displays uncertainty and inability to live in a harsh world. Each character has his or her respective Perfect world. "Amanda lives in the past Laura lives in a world of her own - a world of little glass ornaments,' Tom is 'always so restless,' and identifies himself in his imagination with the sign of the 'sailing vessel with jolly roger." We should analyze them as cases of profound character studies to get a broader and more detailed understanding of the subject of ideal and actual. Amanda's quest for the ideal world is also imposed on her children. She points out to Tom that "life's not easy, it calls for -Spartan endurance," (259) and, later, that "the future becomes the present, the present the past and past turns into everlasting regret if you don't plan for it."(269) She even knows first 
hand what can happen to a southern girl without a home of her own. And her cry comes from experience. Blanche says, "I know so well what becomes of unmarried women who aren't prepared to occupy a position. I've seen such pitiful cases in the South - barely tolerated spinsters living upon the grudging patronage of sister's husband or brother's wife...Eating the crust of humility all their life." (245)

The title of the play Sweet Bird of Youth reminds us immediately of the flight of time and the ravages of time in respect of youth and beauty and damage of memory. Time never stops and every moment some part of the world is falling apart. Could we stop ticking it? The characters in Sweet Bird of Youth are trying to fight time that is futile as time and tide wait for none. The characters vainly try their level best to stop the ticking of the clock. In other words, their efforts to prevent themselves from getting old, fail miserably and they take refuge in illusions. And gradually they come to realize the dangerous consequence of remaining in illusions. They have to get back from the temporary escape; they hid in. The protagonists as much as the audience by the sheer power of poetic characterization, realize that 'clock ticking' is possibly the only way to survive.

In Sweet Bird of Youth, Tennessee Williams traces, once again weaving in of a paradigm of the 'American Dream' in the form of the dreams of youth and success. The result is inevitably the same everywhere i.e. human failure in the face of the laws of nature as aging is irreversible. The pattern of choosing wrong ways to attain something impossible in life constitutes the coterie of Williams, neurotic characters. They are inspired by a success myth, which after alluring them for a while, leaves them unhinged. After having stuffed themselves with wrong notions of achievement, both Chance and Alexandra, the hero and heroine of the play Sweet Bird of Youth, march on the path of illusions, which lead nowhere except to a whirlpool of confusion. Their efforts to retain their youth by making the time stop flying ends in futility for want of logical support. In a significant utterance, Chance says to Princess Alexandra: "It goes tick-tick, it's quieter than your heart-beat, but it's slow dynamite, a gradual explosion, blasting the world as lived into burnt out pieces."(110) Williams himself once said that the passage of time haunted him. To him, time is a cruel thing, and life is a process of burning oneself out and time is the fire that burns it.

The prevalent mood of Sweet Bird of Youth is distraught with disappointment and despair. Alexandra is another kind of Blanche who is not pitted against the circumstances or the environment but pitted against the natural phenomenon of life of which everyone tends to be a victim. The passing away of time is their fear. In plain terms, it means a fear of the gradual march of life towards decay and then sure death. This is the fear that Alexandra and Chance share in common. But, the only difference lies in their characteristic response, which distinguishes one from the other; Alexandra adopts an extreme kind of regressive attitude by thinking only of her past glory, Chance, remembers: "I was a star before big taxes ... And had a husband who was a great merchant prince." (41) Chance marches towards destruction because of his acute obsessions over which, he exercises no control. Both become pathetic figures when they become aware of the failure of their attempts. Princess remarks: "Chance, when I saw you driving under the window with your lead held high, with that terrible stiff-necked pride of the defeated which I know so well; I knew that your come-back had been a failure like mine."(87) They withdraw into themselves and stick to the fading remnants of youth by detecting old age. Princess says: "BEAUTY.' Say it! Say it1. What you had been the beauty. I had it. I say it with pride, no matter how sad, being gone, now." (44)

In Williams' plays, we find that his characters are always struggling to define life by remaining in the ideal world to escape the grim realities of life. The sense of alienation from a heaven of love and confidence to which man or women desires to belong produces an acute awareness of being alone and the ensuing struggle to belong. This desire itself is one way that takes the individual towards his fall because "All my life I have been haunted by the obsession that desire a thing or to love a thing intensely is to place yourself in a vulnerable position, to be possible if not a probable, loser of what you most want." (Sweet Bird 35)

Williams once said: "that time is short, and it does not return again. It is slipping away while I write this and while you read it, and the monosyllable of the clock is Loss, loss, loss unless you devote your heart to its opposition." (qtd. in Nelson 1961, 56) Whatever Williams has said here is eternal truth. But the characters in Sweet Bird of Youth, do not try to understand it and start fighting against this truth of time, which is gradually taking them towards their end. Alexandra's attempt to confront the reality of time takes the form of euphoria of sex, hashish, and an early morning oxygen mask. Other characters also, to escape one thing or the other, take the refuge in illusions. Laura is crippled and also abnormally shy, because of which she cannot have even most normal relationship with people. She takes refuge in her Glass Menagerie, which symbolizes the fragility of her life and the ineffectual nature of her retreat from reality. "Tom is a Youngman with literary ambitions imprisoned in the deadly monotony of a job in a warehouse" (Foster, 2271). He revolts in anguish against his family, furiously cries against his fate, and finally retreats from the present. Jim's life, too, is ruled by illusions. While in the school, he was considered to be something special by the others. Since then he has been thinking high of himself though he is only a shipping clerk. He has taken a course in public speaking and is convinced that he is still something special, designed for great things in future. But we see that up to the end of the play he remains what he hates to be, an ordinary person. Chance, before his boyish charm and his hair leave, is making every effort, even stooping to be servant-lover of the fading actress, to capture a little film glory, yet is sorrowfully conscious of the futility of his attempts.

\section{Conclusion}

In saying all this, Williams is trying to bring home the idea that man's individual efforts towards a search for an ideal world and self-fulfillment comes to nothing, and he should learn, instead, to cautioned in what he hopes to achieve, or else in the long run he suffers. For his suffering, reasons mainly are, that he has set his feet towards unconquerable 
heights and that high flight instigates him to shatter the restrictions society, and family impose on him. In other words, the characters are victims of their weakness, guilt, or illusions, on the one hand, and of the brutality of the world or its crippling mendacity on the other. The society has, through time destroyed a way life and a tradition that is repressive and destructive. In this attempt to overpower this brutal world, the individual has hastened his way towards destruction. And moreover even the means with which he tries to defeat it are illusionary and hence destructive. Williams sees that the ideal world of illusion in which his protagonist would prefer to live is as corrupt as the mundane physical existence in which he confined.

\section{Reference}

Costello, D. P. (1977). Tennessee Williams: fugitive kind. New Jersey: Prentice Hall.

Davis, J.K. (1977). Landscapes of the dislocated mind in Williams' The Glass Menagerie. Tennessee Williams: A Tribute. Ed. Jac Tharpe. Hattiesburg: Heritage Printers, Inc.

Foster, E. E. (1976) Masterplot. (Vol.4 Print). Englewood Cliffs: Salem.

Nelson, Be. (1961).Tennessee Williams: The man and his works. New York: Twayne Publisher.

Phan, Danh. Race and Gender in 1920-1940. Available at <https://prezi.com/pnwabcr2gq4_/race-and-gender-in-1920$1940 />$.

Roudane, M.C. (1997). The Cambridge Companion to Tennessee Williams. UK: Cambridge University Press, print. Spoto, D. (1985). The kindness of strangers: The life of Tennessee Williams. Boston: Little Brown and Company.

Tischler, N. M. (1961). Tennessee Williams: Rebellious puritan. New York: The Citadel Press.

Weales, G. (1977). Tennessee William's achievement in the sixties. New Jersey: Prentice Hall.

Williams, T. (1969) Forward t sweet bird of youth. London: Penguin.

Williams, T. (1968). A street car named desire. London: Martin Secker and Warburg.

Williams, T. (1976). Cat on a hot tin roof new. York: Penguin.

Williams, T. (1958). Orpheus descending. New York: Penguin.

Williams, T. (1945). The glass menagerie. New York: Penguin.

Williams, T. (1968). Sweet bird of youth. London: Penguin Plays.

Wright, S.L. (1913). My brother's keepers. Bloomington: Author House. 